\title{
Toxic Megacolon: Background, Pathophysiology, Management Challenges and Solutions
}

This article was published in the following Dove Press journal:

Clinical and Experimental Gastroenterology

\author{
Jiten Desai ${ }^{1}$ \\ Mohamed Elnaggar (D) ${ }^{2}$ \\ Ahmed A Hanfy ${ }^{2}$ \\ Rajkumar Doshi (iD) ${ }^{2}$ \\ 'Department of Internal Medicine, \\ Nassau University of Medical Center, East \\ Meadow, NY, USA; ${ }^{2}$ Department of \\ Internal Medicine, University of Nevada \\ Reno School of Medicine, Reno, NV, USA
}

\begin{abstract}
Toxic megacolon (TM) is one of the fatal complications of inflammatory bowel disease (IBD) or any infectious etiology of the colon that is characterized by total or partial nonobstructive colonic dilatation and systemic toxicity. It is associated with high morbidity and mortality, and surgical management is necessary for the majority of the cases. An accurate history and physical examination, plain radiographs of the abdomen, sigmoidoscopy, and, most important of all, awareness of the condition facilitate diagnosis in most cases. Operative intervention is warranted when massive hemorrhage, perforation, or peritonitis complicate the clinical scenario or medical therapy fails to control the disease. We sought to review the management challenges of TM and its possible management strategies in this article.
\end{abstract}

Keywords: toxic megacolon, inflammatory bowel disease, management challenges and solutions for toxic megacolon, Clostridium difficile colitis, nitric oxide synthase

\section{Introduction}

Toxic megacolon (TM) is a potentially fatal condition defined as an acute colonic dilatation, greater than $6 \mathrm{~cm}$ in diameter, of the transverse colon, and loss of haustration on radiologic examination in a case of severe colitis. ${ }^{1,2}$ Despite its low prevalence, the outcomes are still unsatisfactory, with in-hospital mortality of $7.9 \% .^{3,4}$ Our review aims are to highlight the crucial aspects and recent advancements regarding epidemiology, pathogenesis, and management of TM.

\section{Epidemiology}

The exact prevalence of TM is underreported. However, the prevalence continues to increase with age. The most common cause of hospital admission included IBD $(51.6 \%)$, followed by septicemia $(10.2 \%)$ and intestinal infections $(4.1 \%) .{ }^{4}$ Some studies reported that the incidence of TM is higher in patients with Ulcerative Colitis (UC) compared to Crohn's disease (CD) (8-10\% in UC compared to $2.3 \%$ in CD). ${ }^{5,6}$ In contrast, others reported its incidence in $\mathrm{CD}$ to be higher than in UC (4.4-6.3\% in CD compared to $1-2.5 \%$ in UC). ${ }^{7}$ Incidence of $\mathrm{TM}$ due to Clostridium difficile (C. diff) was estimated to be $0.4-3 \%$ before 1990; however, it is $4.3 \%$ after $1990 .^{5,6}$ Female gender, age more than 40 years, hypoalbuminemia, acidosis, and high blood urea nitrogen levels are associated with high mortality in a previous study. ${ }^{8}$ The mortality rate in patients with TM is variable. Before 1976 , the mortality rate for TM was $27 \%$ in medically managed cases, however, as low as $19 \%$ in surgically managed cases, which dropped dramatically to a mere $0-2 \%$ in
Correspondence: Rajkumar Dosh Department of Internal Medicine, University of Nevada Reno School of Medicine, II 55 Mill St WII, Reno, NV 89502, USA

Tel + I 201 8858992

Email rdoshi@med.unr.edu 
patients with IBD. Early identification and intensive management may have contributed to the reduced incidence and mortality of TM in IBD. ${ }^{9}$ Patients with fulminant infection require surgical intervention in up to $20 \%$ of cases, carrying mortality rates between 35 and $80 \%{ }^{10,11}$ Colonic perforation is one of the most important predictors of mortality; $44 \%$ of patients underwent emergent colectomy after perforation, while only $2 \%$ of patients without perforation needed the procedure. ${ }^{8}$

\section{Etiology}

UC and CD are important etiologies for TM making it evident that any inflammatory condition of the colon could predispose to TM. ${ }^{5,25,26} \mathrm{TM}$ is a rare but potentially lethal complication of any disease that causes inflammation of the colon, including IBD and Infectious etiologies such as C. diff and cytomegalovirus colitis. ${ }^{5,27,28}$ Other precipitating factors for TM include anti-motility agents, such as anticholinergic medications and narcotics, electrolyte derangements, such as hypokalemia, and diagnostic procedures like barium enema and colonoscopy. ${ }^{29}$

\section{Pathogenesis}

The Massachusetts General Hospital reported its isolated cases of TM from in 1933, 1936, and 1941. ${ }^{12}$ In 1956 , Bockus et al drew attention to it in their study. They described it as "toxic aganglionic megacolon," referring to what they suggested about its pathogenesis, which was described as destructive changes in the nerve plexus in the distal colon. ${ }^{13}$ The mechanism involved in the development of TM remains unclear; however, changes in colonic response to chemical mediators result in defective smooth muscle contraction and lowered basal pressure of the colonic lumen, which may play an essential role in the development of TM. ${ }^{14-17} \mathrm{NO}$ is an inhibitory neurotransmitter that is known to cause relaxation of the colonic smooth muscles. ${ }^{18}$ NO synthase is expressed more in the inflamed mucosa of UC patients compared to noninflamed mucosa, which subsequently leads to suppression of colonic contraction. ${ }^{19-21}$ Selective inhibition of NO synthase reportedly improves the motility, diameter, and intracolonic pressure in animal models with colitis. $^{22}$ Enemas containing NO synthase inhibitor revealed a clinically significant benefit in a patient with TM due to UC. ${ }^{23}$ In contrast to what was suggested by Bockus et al, the inflammation in the case of TM is reportedly caused by the neuromuscular transmission rather than degeneration of the neurons. ${ }^{24}$

\section{Clinical Manifestations}

TM affects both gender and all ages; however, complications can present earlier in patients with IBD. TM occurs in around 5\% of a severe attack of UC. Approximately half of the patients with TM develop this complication in the first three months of their IBD diagnosis. ${ }^{30}$ TM usually occurs in patients with pancolitis, but patients with only left-sided colitis also can develop it. The most common presenting symptom is severe bloody diarrhea. With the clinical decline, patients can also develop hypotension, tachycardia, fever, diffuse abdominal tenderness with distention, and sluggish bowel sounds. One study revealed that patients with TM secondary to $C$. diff colitis had diarrhea as a complaint in all cases, abdominal pain, and distention in up to 82 percent of the cases and the malaise in 91 percent of the cases. ${ }^{31}$ Other laboratory parameters showing progressive systemic toxicity include significant leukocytosis, metabolic alkalosis, and electrolyte derangements.

Nevertheless, strong analgesics or altered mentation might conceal the signs or symptoms of TM. Free perforation can also occur without dilatation of the colon. It is a rare complication, developing in approximately $1 \%$ of patients with UC without TM. ${ }^{32,33}$ Typical presentation of peritonitis may be absent, primarily due to the masking effect of steroid therapy. It is crucial to look for hepatic dullness daily, especially in patients with severe colitis, and are on steroid therapy as they might have a free perforation and not have typical signs of peritonitis. For the same reason, a daily x-ray of the abdomen is recommended.

\section{Diagnosis}

As per the description of Jalan et al, the diagnostic criteria of TM include (a) radiographic evidence of colonic dilatation of more than $6 \mathrm{~cm}$ especially in the transverse colon; (b) any 3 of the following: fever $\left(>38.6^{\circ} \mathrm{C}, 101.5^{\circ} \mathrm{F}\right)$, tachycardia ( $>120$ beats/min), leukocytosis $(>10.5 \times 103 /$ $\mu \mathrm{L}$ ), or anemia; and (c) any of the following: hypotension, hypovolemia, altered mental status, or electrolyte disorders. ${ }^{12}$ The diagnostic purpose of TM is mainly for the diagnosis of the condition and the underlying etiology. Imaging studies are required for the diagnosis of TM as a "megacolon" is defined radiographically by a maximum diameter of $>6 \mathrm{~cm}$. Computed tomography of the abdomen with contrast helps establish the diagnosis and also evaluating for complications that may require immediate 
surgery. Baseline and serial abdominal $\mathrm{x}$ rays help follow the progression of colonic dilatation. Typical features might include dilated transverse or right colon (more than $6 \mathrm{~cm}$ ) more frequently compared to descending colon, sigmoid colon or rectum; deep mucosal ulcerations, segmental colonic wall thinning, air-fluid levels with abnormal haustral pattern and nodular pseudo polyps on radiologic exam. Common nonspecific lab abnormalities associated with TM include leukocytosis with prominent neutrophilia, especially in $C$. diff colitis cases, anemia from gastrointestinal blood loss, metabolic alkalosis secondary to volume depletion, hypokalemia, hypoalbuminemia and elevated inflammatory markers including ESR and CRP.

A complete colonoscopy is extremely risky in patients with TM because it can cause colonic perforation. A limited endoscopic examination without bowel preparation (eg, proctoscopy or sigmoidoscopy) is safer compared to complete colonoscopy. It is useful to diagnose an inflammatory (eg, [IBD]) or infectious process (eg, cytomegalovirus [CMV] or $C$. diff colitis) in the rectum or sigmoid colon. Nevertheless, a sigmoidoscopy can miss CMV inclusion bodies as classic ulcers are generally present in the ascending colon in a majority of the cases. ${ }^{34}$

\section{Treatment}

The main objective for the treatment of TM is to reduce the inflammation, improve the motility of the colon, and to prevent free perforation. If UC gets complicated with colonic dilatation, fluid replacement and intravenous steroid therapy is recommended, along with addressing electrolyte derangements aggressively. Bowel rest and nasogastric decompression can also help in the reduction of air and fluid within the GI tract. Both medical and surgical teams should co-manage patients on admission with daily evaluation.

Inpatient evaluation, preferably in the closed observation unit, with periodic examinations, help assess for signs of toxicity. Serial labs, including $\mathrm{CBC}$ and Electrolytes, along with clinical abdominal x-ray, should be performed twice a day initially upon admission and subsequently daily as the condition improves. Maneuvers to decrease abdominal distension by permitting the redistribution or passing of colon gas could be another conservative management strategy. Encouraging patients to walk around, using knee-elbow maneuver in the prone position, rotating patient who is bed-bound and inserting a rectal tube helps reducing bowel distension. ${ }^{30}$ Enteral feeding can be initiated as soon as the patient shows signs of improvement to promote gut motility. Total parental nutrition (TPN) is of limited value in patients with TM from any cause. TPN provides no proven clinical benefit in terms of avoiding surgical intervention in patients with colitis due to UC. ${ }^{35}$ When it comes to the specific medical or surgical therapy for TM must target the underlying etiology:

Inflammatory bowel disease - 5-ASA compounds and Sulfasalazine have no role in patients with IBD-related TM and should be commenced only after the acute attack resolves. In a few cases, an acute attack of TM might cooccur with the initiation of 5-ASA compounds.

\section{Glucocorticoids}

Intravenous glucocorticoids (hydrocortisone $100 \mathrm{mg}$ every 6 to 8 hours) are the mainstay of therapy for all patients with TM secondary to IBD and are not associated with a higher risk of perforation. ${ }^{36}$ However, this approach is based on limited observational data and clinical experience. Dexamethasone, by diminishing the expression of NO synthase, has been reported to decrease the colonic diameter. Most providers consider methylprednisolone because of its lower potassium wasting and sodium retaining properties, while others prefer prednisolone as the oral and parenteral doses are the same.

\section{Infliximab or Cyclosporine}

Patients with IBD-related TM who are refractory to three days of intravenous glucocorticoid therapy should receive either Infliximab or Cyclosporine as the secondline therapy. Infliximab is the preferred second-line treatment for all patients with IBD-related TM. Cyclosporine should be reserved for those who cannot tolerate Infliximab, and there is only evidence for its effectiveness in UC, not CD. (See Table 1) Data suggest that cyclosporine may provide an initial response rate of as high as $80 \%$. After a follow-up period, the response rate decreases to approximately $40 \%$. Although further studies are required, cyclosporine therapy may prevent the need for urgent surgery, allowing an elective surgery to be performed under the more controlled scenario. Most patients who develop IBD-related TM have UC; some have indeterminate colitis or Crohn's colitis. Since these three conditions may not be readily distinguishable during an acute flare-up such as TM, many authors suggest treating all IBD-related TM with the same approach. 
Table I Different Medication Use for the Treatment of Toxic Megacolon

\begin{tabular}{|c|c|c|c|}
\hline Medication & Indications & Mechanism of Action/Dosages & $\begin{array}{l}\text { Therapeutic Benefits/Risks/ } \\
\text { Complications }\end{array}$ \\
\hline $\begin{array}{l}\text { Sulfasalazine/ } \\
\text { 5-ASA } \\
\text { compounds }\end{array}$ & $\begin{array}{l}\text {-In IBD related Toxic megacolon not as } \\
\text { first line, after attack resolves }\end{array}$ & -Anti-inflammatory effects & $\begin{array}{l}\text {-No enough data supporting beneficial } \\
\text { use in IBD related toxic megacolon, it } \\
\text { can be used after initial attack resolves }\end{array}$ \\
\hline Glucocorticoids & $\begin{array}{l}\text {-First-line therapy for all patients with } \\
\text { IBD-related toxic megacolon } \\
\text {-Methylprednisolone due to its lower } \\
\text { sodium retaining and potassium wasting } \\
\text { properties, while other clinicians prefer } \\
\text { prednisolone since the parenteral dose } \\
\text { is equal to the oral dose }\end{array}$ & $\begin{array}{l}\text {-Decreases diameter of colon by } \\
\text { reducing nitrous oxide synthetase } \\
\text {-Hydrocortisone } 100 \mathrm{mg} \text { IV every } 6 \text { to } 8 \\
\text { hours } \\
\text {-Methylprednisone } 60 \mathrm{mg} \text { daily for } 5 \\
\text { days }^{37,38}\end{array}$ & $\begin{array}{l}\text {-Not associated with risk of colonic } \\
\text { perforation }\end{array}$ \\
\hline Cyclosporine & $\begin{array}{l}\text { If no response to Glucocorticoids } \\
\text { within } 3 \text { days }\end{array}$ & $\begin{array}{l}\text {-Inhibits T-lymphocyte function that is } \\
\text { essential for the propagation of } \\
\text { inflammation } \\
\text {-Rapid response } 4 \mathrm{mg} / \mathrm{kg} \text { per day; } 82 \% \\
\text { with clinical improvement with } \\
\text { possibility of avoiding colectomy }{ }^{39}\end{array}$ & $\begin{array}{l}\text {-Cyclosporine should be reserved for } \\
\text { those who cannot tolerate infliximab and } \\
\text { there is only evidence for its effectiveness in } \\
\text { ulcerative colitis, not Crohn's disease } \\
\text {-Cyclosporine better to be avoided in elderly } \\
\text { patients with significant co-morbid conditions } \\
\text { as well as patients in whom colectomy is likely } \\
\text { to be necessary in near future }\end{array}$ \\
\hline Infliximab & $\begin{array}{l}\text { If no response to Glucocorticoids } \\
\text { within } 3 \text { days }\end{array}$ & $\begin{array}{l}\text {-Blocks the action of TNF- } \alpha \text { by } \\
\text { preventing it from binding to its receptor } \\
\text { in the cell, but it also causes } \\
\text { programmed cell death of TNF- } \alpha \text { - } \\
\text { expressing activated T lymphocytes that } \\
\text { mediate inflammation } \\
\text {-Infliximab } 5 \mathrm{mg} / \mathrm{kg} \text { ( } 2 \text { or } 3 \text { infusions) }\end{array}$ & $\begin{array}{l}\text {-Effective as rescue therapy for severe } \\
\text { steroid refractory colitis in up to } 70 \% \text { of } \\
\text { instancing } \\
\text {-Clinical response usually occurs within } \\
3 \text { to } 7 \text { days of treatment } \\
\text { - Infliximab also appears to induce } \\
\text { a long-term remission comparable to } \\
\text { that seen with cyclosporine }\end{array}$ \\
\hline
\end{tabular}

\section{C. difficile colitis}

For patients with TM due to severe $C$. diff colitis, the inciting antibiotics should be withdrawn immediately. Steroids are contraindicated in TM due to an infectious etiology, including $C$. diffcolitis.

Empiric antibiotics are indicated as mortality due to TM correlates with the development of sepsis. Approximately half of the acute dilatation cases resolve with medical therapy alone. ${ }^{32}$ Perforation of colon is the most critical predictor of mortality ( $44 \%$ of cases require emergent surgical intervention following perforation vs only $2 \%$ of cases requiring it without perforation), ${ }^{9}$ a critical aspect of management is to decide the optimal time for surgical intervention. Generally, cases that do not improve after 2-3 days of medical management require a surgical evaluation. ${ }^{41}$

Surgery is indicated in patients with colonic perforation, necrosis, or full-thickness ischemia, intraabdominal hypertension or abdominal compartment syndrome, clinical signs of peritonitis, or worsening abdominal exam despite adequate medical therapy, and end-organ failure. Besides, white blood cell count $>50,000$ cell $/ \mathrm{mL}$ and serum lactate level of $>5$ $\mathrm{mmol} / \mathrm{L}$ are relative indications for surgical intervention. The timing of surgery in TM is still a matter of controversy and varies by the underlying etiology of the TM. Although the main objective of all medical therapy is to avoid the need for surgical management, delaying surgery may ultimately increase the risk of complications such as abdominal compartment syndrome or perforation. Careful monitoring for any signs of impending perforation is vital. Patients developing abdominal distention, rebound tenderness, or hemodynamic instability require emergent surgical intervention. Further management is debatable for patients who achieve remission with medical management. According to one study, almost half of the patients who were managed successfully for TM 
Table 2 Different Surgical Intervention for the Management of Toxic Megacolon

\begin{tabular}{|c|c|}
\hline \multicolumn{2}{|c|}{ Surgical Intervention Indications } \\
\hline \multicolumn{2}{|c|}{$\begin{array}{l}\text { - Failure to respond to one of the second-line agents (infliximab or } \\
\text { cyclosporine) for three days. }\end{array}$} \\
\hline \multicolumn{2}{|c|}{$\begin{array}{l}\text { - Toxic megacolon while on either infliximab or cyclosporine should } \\
\text { undergo surgery right away }\end{array}$} \\
\hline \multicolumn{2}{|c|}{$\begin{array}{l}\text { - Patients with colonic perforation, abdominal compartment } \\
\text { syndrome, full thickness colonic wall ischemia, worsening clinical } \\
\text { status despite proper medical management, Leukocytosis }>50,000 \\
\text { cell } / \mathrm{mL} \text { and serum lactate level of }>5 \mathrm{mmol} / \mathrm{L} \text { are relative indications } \\
\text { for surgery. }\end{array}$} \\
\hline \multicolumn{2}{|c|}{$\begin{array}{l}\text {-Early surgical intervention before colonic perforation has a lower mortality } \\
\text { rates compared to colectomy after perforation ( } 8 \text { versus } 40 \text { percent })^{9}\end{array}$} \\
\hline Surgical Intervention & Description \\
\hline $\begin{array}{l}\text { Subtotal colectomy with } \\
\text { end-ileostomy }\end{array}$ & $\begin{array}{l}\text { Urgent surgery of choice for toxic } \\
\text { megacolon secondary to either Crohn's } \\
\text { disease or Ulcerative colitis. } \\
{ }^{6} \\
\text { - Compared to single stage proctocolectomy, } \\
\text { it has lower mortality ( } 9 \%) \text { with possibility of } \\
\text { anastomosis subsequently in most patients } \\
\text { - Common complications include small } \\
\text { bowel obstruction ( } 20 \%) \text {, wound infection } \\
(18 \%) \text { and intraabdominal abscess }(17 \%) \text {. }\end{array}$ \\
\hline $\begin{array}{l}\text { Total abdominal } \\
\text { colectomy }\end{array}$ & $\begin{array}{l}\text { Recommended procedure for patients with } \\
\text { perforated colon, abdominal compartment } \\
\text { syndrome or colonic necrosis. }\end{array}$ \\
\hline $\begin{array}{l}\text { Partial or segmental } \\
\text { colectomy }\end{array}$ & $\begin{array}{l}\text { No longer performed due to a higher } \\
\text { mortality and reoperation rate. }\end{array}$ \\
\hline $\begin{array}{l}\text { Diverting loop } \\
\text { ileostomy/colonic lavage }\end{array}$ & $\begin{array}{l}\text { An alternative surgical intervention that } \\
\text { has been associated low mortality in } \\
\text { some studies. }{ }^{43}\end{array}$ \\
\hline
\end{tabular}

eventually required surgical intervention. ${ }^{42}$ Because of these facts, some providers offer elective surgical evaluation after the resolution of an acute attack of TM. Early surgical intervention before colonic perforation has a lower mortality rate compared to colectomy after perforation ( 8 versus 40 percent). ${ }^{9}$ (See Table 2).

\section{Additional Therapies}

Leukocytapheresis (LCAP) is useful in the management of TM. A series of six patients whose conditions had failed to improve after treatment with high-dose steroids and antibiotics were enrolled in a study. In four cases, the TM resolved by the morning after initiation of treatment with LCAP. In two patients, the TM resolved approximately 40 hours later. Improvement continued in four out of the six patients. $^{44}$

Shetler et al reported that colonoscopic decompression and intracolonic vancomycin administration in the management of acute pseudomembranous colitis associated with TM is safe and effective in approximately $57-71 \%$ of the cases. ${ }^{45}$

Hyperbaric oxygen therapy has also been reported to be effective in the management of TM, but further studies are needed to confirm these results. ${ }^{46}$

Tacrolimus was successfully used in 1 case study in a patient with steroid-refractory UC complicated by TM. However, further studies are required to validate its use. ${ }^{47}$

Intravenous immune globulin (IVIG) may potentially be an adjunct therapy in patients with severe $\mathrm{C}$ diff infection with megacolon, taking into account the possibility of adverse effects. ${ }^{48}$

\section{Special Populations HIVIAIDS patients}

An aggressive exploration of infectious and noninfectious etiology is a must, including radiological imaging and early limited endoscopic workup. Patients with cytomegalovirus (CMV) colitis or $C$. diff infection respond poorly to medical management only and often require surgical intervention. ${ }^{49,50}$ Critically ill patients with advanced AIDS who are poor surgical candidates could be managed by supportive therapy, antibiotics, and careful colonic decompression.

\section{Pregnant women}

Women with known risk factors for TM (most commonly UC) should plan conception during a state of remission. ${ }^{51}$ Patients who are in remission at the conception are likely to remain in remission during pregnancy. In the case of TM in pregnancy primarily due to UC, high-dose intravenous glucocorticoids therapy is effective in three-fourth cases of severe colitis, the remainder requiring either Infliximab or emergent surgical intervention. ${ }^{52,53}$

Management of fulminant colitis during pregnancy is challenging as the gravid uterus can restrict a thorough abdominal examination, and diagnostic radiation could be teratogenic. ${ }^{54}$ In pregnancy, hemoglobin, and serum albumin level drop, while other inflammatory markers, including the ESR and CRP rise; so, these blood tests are not reliable measures of disease activity. Urgent colon surgery can increase the risks of preterm delivery and spontaneous abortions. 


\section{Prognosis}

The mortality rates for TM are inconsistent. Before 1976, the death rate in 604 cases of TM was 27 percent (43 out of 160) for patients who were managed medically and 19 percent in 444 patients who underwent surgical intervention. ${ }^{55}$ The in-hospital mortality for TM further decreased from 9.2 to 6.5 percent in 2010 through $2014 .{ }^{4}$ Colonic perforation is associated with a significantly worse prognosis, with the mortality rate increased by three- to fivefold. ${ }^{6,8}$

The etiology of TM can also affect the prognosis, TM secondary to infectious etiology has a better prognosis than patients with TM secondary to IBD who have been treated with biologics; however, this result is mainly based upon a small group of studies. The prognosis is especially good when colonic dilatation complicates acute self-limited colitis and is managed promptly. ${ }^{56}$ Nevertheless, the mortality rates dropped significantly to less than 2 percent in patients with IBD, probably related to diverse factors, including early identification of TM, the rapid escalation from glucocorticoid therapy to biologics (or cyclosporine), increasing use of biologics and accelerated dosing, aggressive medical management, prompt surgical intervention, and better post-surgical care. ${ }^{9}$

A review of patients with TM due to $C$. diff infection between 1968 and 1992 revealed an overall mortality of 31 to 35 percent. ${ }^{31}$ In other studies, the overall mortality from TM secondary to severe $C$. diff infection was 64 to 67 percent, and 71 to 100 percent in cases which were managed surgically. ${ }^{31,57}$ These studies show that patients with TM due to $C$. diff infection will do better with medical management alone, and surgery may offer a nominal benefit. However, surgery should not be postponed in acutely sick patients.

The difference in mortality rates may also be due to the biases of medical or surgical providers. Two studies have revealed that 68 to 75 percent of cases of TM managed medically did not require a surgical intervention later and have maintained remission for up to six years. ${ }^{6,9}$ Surgical studies reveal up to a 50 percent rate of future surgical intervention, including colectomy in patients with TM who initially responded well to medical treatment alone. ${ }^{55,58}$ Timely surgical interventions decreased the mortality rate significantly from 22 to 1.2 percent in one report. ${ }^{59}$ The key points of this review article have been summarized in Table 3.
Table 3 Key Points to Keep in Mind when managing Toxic Megacolon

\begin{tabular}{l}
\hline Key points of the Review Article: \\
\hline I. Toxic megacolon (TM) was thought to be a complication for ulcerative \\
colitis (UC) specifically. Later on, the Crohn's disease (CD) was found \\
to be a cause, and gradually it becomes evident that any inflammatory \\
condition of the colon could predispose to TM.
\end{tabular}

2. Accurate history and physical examination, plain radiographs of the abdomen, sigmoidoscopy and, most important of all, awareness of the condition facilitate diagnosis in most cases.

3. The most common cause of hospital admission included Inflammatory bowel disease (IBD) (5I.6\%), followed by septicemia (10.2\%) and intestinal infections (4.1\%).

4. Computed tomography of the abdomen with contrast is usually performed to establish the diagnosis and also evaluating for complications that may require immediate surgery. Baseline and serial abdominal $x$ rays are then performed to follow the progression of colonic dilatation.

5. Patients should be admitted and evaluated, preferably in the intensive care unit, with frequent examinations to assess for signs of toxicity.

6. Both medical and surgical teams should co-manage patients on admission with daily evaluation.

7. Female gender, age more than 40 years, hypoalbuminemia, acidosis, and high blood urea nitrogen levels are associated with high mortality in a previous study. This patient population requires a special attention from the admission.

8. It is important to examine the abdomen for hepatic dullness every day in patients who have severe colitis and are taking highdose glucocorticoids because they might have a free perforation and not have classic signs of peritonitis.

9. The main goal for treatment for TM is to treat the underlying inflammation, restoring colonic motility, and preventing free colonic perforation.

10. In HIV infection patients with TM, an aggressive search for infectious and noninfectious causes is essential, including early limited endoscopy and imaging studies. Patients with cytomegalovirus (CMV) colitis or C. difficile infection respond poorly to medical therapy and often require emergent subtotal colectomy and ileostomy.

II. Women with known risk factors for toxic megacolon (most commonly ulcerative colitis) should plan conception during a state of remission.

\section{Conclusion}

$\mathrm{TM}$ is a condition best approached through the combined efforts of the medical and surgical team working with the patient. Medical therapy is the first-line treatment in most cases, but objective measures of improvement should be discussed before treatment initiation. If the patient manifests signs of hemorrhage, peritonitis, or perforation, surgery is 
emergently indicated. Subtotal/total colectomy and ileostomy is the procedure of choice in most instances, and a laparoscopic approach is potentially favored when possible and feasible.

\section{Abbreviations}

$\mathrm{TM}$, toxic megacolon; IBD, inflammatory bowel disease; UC, ulcerative colitis; CD, Crohn's disease; $C$. diff, Clostridium difficile; NO, nitric oxide; TPN, total parenteral nutrition; LCAP, leukocytapheresis.

\section{Disclosure}

The authors have nothing to disclose.

\section{References}

1. Bartram CI. Radiology in the current assessment of ulcerative colitis. Gastrointest Radiol. 1977;1(4):383-392. doi:10.1007/BF02256402

2. Lennard-Jones JE, Ritchie JK, Hilder W, Spicer CC. Assessment of severity in colitis: a preliminary study. Gut. 1975;16(8):579-584. doi:10.1136/gut.16.8.579

3. Ciccocioppo R, Corazza GR. In-hospital mortality for toxic megacolon. Intern Emerg Med. 2018;13(6):837-838. doi:10.1007/ s11739-018-1919-6

4. Doshi R, Desai J, Shah Y, Decter D, Doshi S. Incidence, features, in-hospital outcomes and predictors of in-hospital mortality associated with toxic megacolon hospitalizations in the United States. Intern Emerg Med. 2018;13(6):881-887. doi:10.1007/s11739-0181889-8

5. Autenrieth DM, Baumgart DC. Toxic megacolon. Inflamm Bowel Dis. 2012;18(3):584-591. doi:10.1002/ibd.21847

6. Ausch C, Madoff RD, Gnant M, et al. Aetiology and surgical management of toxic megacolon. Colorectal Dis. 2006;8(3):195-201. doi:10.1111/j.1463-1318.2005.00887.x

7. Grieco MB, Bordan DL, Geiss AC, Beil AR. Toxic megacolon complicating Crohn's colitis. Ann Surg. 1980;191(1):75-80. doi:10.1097/00000658-198001000-00015

8. Greenstein AJ, Sachar DB, Gibas A, et al. Outcome of toxic dilatation in ulcerative and Crohn's colitis. J Clin Gastroenterol. 1985;7 (2):137-143. doi:10.1097/00004836-198504000-00007

9. Danovitch SH. Fulminant colitis and toxic megacolon. Gastroenterol Clin North Am. 1989;18(1):73-82.

10. Klipfel AA, Schein M, Fahoum B, Wise L. Acute abdomen and Clostridium difficile colitis: still a lethal combination. Dig Surg. 2000;17(2):160-163. doi:10.1159/000018821

11. Grundfest-Broniatowski S, Quader M, Alexander F, Walsh RM, Lavery I, Milsom J. Clostridium difficile colitis in the critically ill. Dis Colon Rectum. 1996;39(6):619-623. doi:10.1007/BF02056938

12. Jalan KN, Sircus W, Card WI, et al. An experience of ulcerative colitis. I. Toxic dilation in 55 cases. Gastroenterology. 1969;57 (1):68-82. doi:10.1016/S0016-5085(19)33962-9

13. Bockus HL, Roth JL, Buchman E, et al. Life history of nonspecific ulcerative colitis: relation of prognosis to anatomical and clinical varieties. Gastroenterologia. 1956;86(5):549-581. doi:10.1159/ 000200623

14. Tomita R, Tanjoh K, Fujisaki S, Fukuzawa M. Peptidergic nerves in the colon of patients with ulcerative colitis. Hepatogastroenterology. 2000;47(32):400-404.

15. Tomita R, Tanjoh K. Role of nitric oxide in the colon of patients with ulcerative colitis. World J Surg. 1998;22(1):88-91; discussion 92. doi: $10.1007 / \mathrm{s} 002689900354$
16. Pons L, Droy-Lefaix MT, Bueno L. Leukotriene D4 participates in colonic transit disturbances induced by intracolonic administration of trinitrobenzene sulfonic acid in rats. Gastroenterology. 1992;102 (1):149-156. doi:10.1016/0016-5085(92)91794-5

17. Snape WJ, Kao HW. Role of inflammatory mediators in colonic smooth muscle function in ulcerative colitis. Dig Dis Sci. 1988;33(3 Suppl):65S-70S. doi:10.1007/BF01538133

18. Boeckxstaens GE, Pelckmans PA, Herman AG, Van Maercke YM. Involvement of nitric oxide in the inhibitory innervation of the human isolated colon. Gastroenterology. 1993;104(3):690-697. doi:10.1016/ 0016-5085(93)91003-Z

19. Palatka K, Serfozo Z, Vereb Z, et al. Changes in the expression and distribution of the inducible and endothelial nitric oxide synthase in mucosal biopsy specimens of inflammatory bowel disease. Scand J Gastroenterol. 2005;40(6):670-680. doi:10.1080/00365520510015539

20. Lundberg S, Holst M, Hellstrom PM. Expression of iNOS mRNA associated with suppression of colonic contraction in rat colitis. Acta Physiol (Oxf). 2006;187(4):489-494. doi:10.1111/j.1748-1716.2006.01576.x

21. Mourelle M, Casellas F, Guarner F, et al. Induction of nitric oxide synthase in colonic smooth muscle from patients with toxic megacolon. Gastroenterology. 1995;109(5):1497-1502. doi:10.1016/ 0016-5085(95)90636-3

22. Mourelle M, Vilaseca J, Guarner F, Salas A, Malagelada JR. Toxic dilatation of colon in a rat model of colitis is linked to an inducible form of nitric oxide synthase. Am J Physiol. 1996;270(3 Pt 1):G425430. doi:10.1152/ajpgi.1996.270.3.G425

23. Schworer H, Bohn M, Waezsada SY, Raddatz D, Ramadori G. Successful treatment of megacolon associated with colitis with a nitric oxide synthase inhibitor. Am J Gastroenterol. 2001;96 (7):2273-2274. doi:10.1111/j.1572-0241.2001.03986.x

24. Bockus HL, Roth JL, Buchman E, Kalser M, Staub WR,Finkelstein A and Valdes-Dapena ALife history of nonspecific ulcerative colitis: relation of prognosis to anatomical and clinical varieties. Gastroenterologia1956;86:549-581.26.

25 Gan SI, Beck PL. A new look at toxic megacolon: an update and review of incidence, etiology, pathogenesis, and management. $\mathrm{Am}$ $J$ Gastroenterol. 2003;98(11):2363-2371. doi:10.1111/j.15720241.2003.07696.x

26. Maddu KK, Mittal P, Shuaib W, Tewari A, Ibraheem O, Khosa F. Colorectal emergencies and related complications: a comprehensive imaging review-imaging of colitis and complications. AJR Am $J$ Roentgenol. 2014;203(6):1205-1216. doi:10.2214/AJR.13.12250

27. Skomorochow E, Pico J. Toxic Megacolon. Treasure Island (FL): StatPearls; 2020

28. Hommes DW, Sterringa G, van Deventer SJ, Tytgat GN, Weel J. The pathogenicity of cytomegalovirus in inflammatory bowel disease: a systematic review and evidence-based recommendations for future research. Inflamm Bowel Dis. 2004;10(3):245-250. doi:10.1097/ 00054725-200405000-00011

29. Hartong WA, Arvanitakis C, Skibba RM, Klotz AP. Treatment of toxic megacolon. A comparative review of 29 patients. Am J Dig Dis. 1977;22(3):195-200. doi:10.1007/BF01072276

30. Roys G, Kaplan MS, Juler GL. Surgical management of toxic megacolon. Am J Gastroenterol. 1977;68(2):161-166.

31. Trudel JL, Deschenes M, Mayrand S, Barkun AN. Toxic megacolon complicating pseudomembranous enterocolitis. Dis Colon Rectum. 1995;38(10):1033-1038. doi:10.1007/BF02133974

32. Greenstein AJ, Aufses AH. Differences in pathogenesis, incidence and outcome of perforation in inflammatory bowel disease. Surg Gynecol Obstet. 1985;160(1):63-69.

33. Greenstein AJ, Barth JA, Sachar DB, Aufses AH. Free colonic perforation without dilatation in ulcerative colitis. Am J Surg. 1986;152(3):272-275. doi:10.1016/0002-9610(86)90256-4

34. Alemayehu G, Jarnerot G. Colonoscopy during an attack of severe ulcerative colitis is a safe procedure and of great value in clinical decision making. Am J Gastroenterol. 1991;86(2):187-190. 
35. Dickinson RJ, Ashton MG, Axon AT, Smith RC, Yeung CK, Hill GL. Controlled trial of intravenous hyperalimentation and total bowel rest as an adjunct to the routine therapy of acute colitis. Gastroenterology. 1980;79(6):1199-1204. doi:10.1016/0016-5085(80)90913-0

36. Norland CC, Kirsner JB. Toxic dilatation of colon (toxic megacolon): etiology, treatment and prognosis in 42 patients. Medicine (Baltimore). 1969;48(3):229-250. doi:10.1097/00005792-196905000-00003

37. Travis SP, Stange EF, Lemann M, et al. European evidence-based Consensus on the management of ulcerative colitis: current management. J Crohns Colitis. 2008;2(1):24-62.

38. Kornbluth A, Sachar DB. Practice parameters committee of the American college of G. Ulcerative colitis practice guidelines in adults: American college of gastroenterology, practice parameters committee. Am J Gastroenterol. 2010;105(3):501-523; quiz 524. doi:10.1038/ajg.2009.727

39. Lichtiger S, Present DH, Kornbluth A, et al. Cyclosporine in severe ulcerative colitis refractory to steroid therapy. $N$ Engl J Med. 1994;330(26):1841-1845. doi:10.1056/NEJM199406303302601

40. Kohn A, Daperno M, Armuzzi A, et al. Infliximab in severe ulcerative colitis: short-term results of different infusion regimens and long-term follow-up. Aliment Pharmacol Ther. 2007;26(5):747-756. doi:10.1111/j.1365-2036.2007.03415.x

41. Panos MZ, Wood MJ, Asquith P. Toxic megacolon: the knee-elbow position relieves bowel distension. Gut. 1993;34(12):1726-1727. doi:10.1136/gut.34.12.1726

42. Grant CS, Dozois RR. Toxic megacolon: ultimate fate of patients after successful medical management. Am J Surg. 1984;147 (1):106-110. doi:10.1016/0002-9610(84)90042-4

43. Neal MD, Alverdy JC, Hall DE, Simmons RL, Zuckerbraun BS. Diverting loop ileostomy and colonic lavage: an alternative to total abdominal colectomy for the treatment of severe, complicated Clostridium difficile associated disease. Ann Surg. 2011;254 (3):423-429. doi:10.1097/SLA.0b013e31822ade48

44. Sawada K, Egashira A, Ohnishi K, Fukunaga K, Kusaka T, Shimoyama T. Leukocytapheresis (LCAP) for management of fulminant ulcerative colitis with toxic megacolon. Dig Dis Sci. 2005;50 (4):767-773. doi:10.1007/s10620-005-2571-3

45. Shetler K, Nieuwenhuis R, Wren SM, Triadafilopoulos G. Decompressive colonoscopy with intracolonic vancomycin administration for the treatment of severe pseudomembranous colitis. Surg Endosc. 2001;15(7):653-659. doi:10.1007/s004640080104
46. Knroki K, Masuda A, Uehara H, Kuroki A. A new treatment for toxic megacolon. Lancet. 1998;352(9130):782. doi:10.1016/S01406736(98)95043-7

47. Pascu M, Muller AR, Wiedenmann B, Dignass AU. Rescue therapy with tacrolimus in a patient with toxic megacolon. Int $J$ Colorectal Dis. 2003;18(3):271-275. doi:10.1007/s00384-002-0458-8

48. Shah PJ, Vakil N, Kabakov A. Role of intravenous immune globulin in streptococcal toxic shock syndrome and Clostridium difficile infection. Am J Health Syst Pharm. 2015;72(12):1013-1019. doi:10.2146/ajhp140359

49. Beaugerie L, Ngo Y, Goujard F, et al. Etiology and management of toxic megacolon in patients with human immunodeficiency virus infection. Gastroenterology. 1994;107(3):858-863. doi:10.1016/ 0016-5085(94)90137-6

50. Davidson T, Allen-Mersh TG, Miles AJ, et al. Emergency laparotomy in patients with AIDS. Br J Surg. 1991;78(8):924-926. doi:10.1002/ bjs. 1800780809

51. Quddus A, Martin-Perez B, Schoonyoung H, Albert M, Atallah S. Toxic megacolon during pregnancy in ulcerative colitis: a case report. Int J Surg Case Rep. 2015;11:83-86. doi:10.1016/j.ijscr.2015.04.033

52. Truelove SC, Willoughby CP, Lee EG, Kettlewell MG. Further experience in the treatment of severe attacks of ulcerative colitis. Lancet. 1978;2 (8099):1086-1088. doi:10.1016/S0140-6736(78)91816-0

53. Anderson JB, Turner GM, Williamson RC. Fulminant ulcerative colitis in late pregnancy and the puerperium. J R Soc Med. 1987;80 (8):492-494. doi:10.1177/014107688708000812

54. Boulton R, Hamilton M, Lewis A, Walker P, Pounder R. Fulminant ulcerative colitis in pregnancy. Am J Gastroenterol. 1994;89(6):931-933.

55. Strauss RJ, Flint GW, Platt N, Levin L, Wise L. The surgical management of toxic dilatation of the colon: a report of 28 cases and review of the literature. Ann Surg. 1976;184(6):682-688. doi:10.1097/ 00000658-197612000-00004

56. Snowden JA, Young MJ, McKendrick MW. Dilatation of the colon complicating acute self-limited colitis. Q J Med. 1994;87(1):55-62.

57. Rubin MS, Bodenstein LE, Kent KC. Severe Clostridium difficile colitis. Dis Colon Rectum. 1995;38(4):350-354. doi:10.1007/ BF02054220

58. Greenstein AJ, Kark AE, Dreiling DA. Crohn's disease of the colon. III. Toxic dilatation of the colon in Crohn's colitis. Am J Gastroenterol. 1975;63(2):117-128.

59. Flatmark A, Fretheim B, Gjone E. Early colectomy in severe ulcerative colitis. Scand J Gastroenterol. 1975;10(4):427-431.
Clinical and Experimental Gastroenterology

\section{Publish your work in this journal}

Clinical and Experimental Gastroenterology is an international, peerreviewed, open access, online journal publishing original research, reports, editorials, reviews and commentaries on all aspects of gastroenterology in the clinic and laboratory. This journal is indexed on American Chemical Society's Chemical Abstracts Service (CAS).
The manuscript management system is completely online and includes a very quick and fair peer-review system, which is all easy to use. Visit http://www.dovepress.com/testimonials.php to read real quotes from published authors. 